\title{
Impaired insulin signaling in the liver of transgenic rats with low circulating growth hormone levels
}

\author{
Y Furuhata, $\mathbf{T}$ Yonezawa, $\mathbf{M}$ Takahashi ${ }^{\mathbf{1}}$ and $\mathbf{M}$ Nishihara \\ Department of Veterinary Physiology, Veterinary Medical Science, University of Tokyo, 1-1-1 Yayoi, Bunkyo-ku, Tokyo 113-8657, Japan \\ ${ }^{1}$ Ajinomoto Co. Inc., Kawasaki 210-0801, Japan \\ (Requests for offprints should be addressed to M Nishihara; Email: amnishi@mail.ecc.u-tokyo.ac.jp)
}

\begin{abstract}
GH is known to regulate glucose and lipid metabolism as well as body growth. Controversy exists as to whether $\mathrm{GH}-$ deficient adults are indeed insulin sensitive or insulin resistant. In GH-deficient animal models, however, no clear observation indicating insulin resistance has been made, while increased insulin sensitivity has been reported in those animals. We have produced human $\mathrm{GH}(\mathrm{hGH})$ transgenic rats characterized by low circulating hGH levels and virtually no endogenous rat GH secretion. Although the body length of the transgenic rat is normal, they develop massive obesity and insulin resistance, indicating that the transgenic rat is a good model for the analysis of insulin resistance under GH deficiency. In this study, we have examined how GH deficiency affects the early steps of insulin signaling in the liver of the transgenic rat.

Circulating glucose and insulin concentrations were significantly higher in the transgenic rats than in their littermates. In addition, impaired glucose tolerance was observed in the transgenic rat. The amount of insulin receptor was smaller in the liver of the transgenic rat, resulting in decreased tyrosine phosphorylation in response to insulin stimulation. The amounts of insulin receptor
\end{abstract}

substrate-1 and -2 (IRS-1 and -2) and insulin-stimulated phosphorylation of IRSs were also smaller in the transgenic rat. Despite the decrease in tyrosine phosphorylation levels of IRSs being mild to moderate (45\% for IRS-1 and 16\% for IRS-2), associated phosphatidylinositol 3-kinase (PI3-kinase) activity was not increased by insulin stimulation at all in the transgenic rat. To elucidate whether this discrepancy resulted from the alteration in binding of the p85 subunit of PI3-kinase to phosphotyrosine residues of the IRSs, we determined the amount of $\mathrm{p} 85$ subunit in the immunocomplexes with anti-phosphotyrosine antibody. Insulin did not affect the amount of p85 subunit associated with phosphotyrosine in the transgenic rats, while it significantly increased in the controls, indicating that alteration may have occurred at the sites of phosphorylated tyrosine residues in IRSs.

These results suggest that GH deficiency in the transgenic rat leads to impairment in at least the early steps of insulin signaling in the liver with a resultant defect in glucose metabolism.

Journal of Endocrinology (2002) 172, 127-136

\section{Introduction}

Insulin is a major regulator of glucose homeostasis, and a deficiency in insulin action would cause diabetes mellitus. Insulin signaling is initiated by the activation of insulin receptor tyrosine kinase, leading to the phosphorylation of intracellular receptor substrates, including insulin receptor substrates-1 and -2 (IRS-1 and IRS-2), which contain over 20 potential tyrosine phosphorylation sites (Sun et al. 1993, 1995). The possible tyrosine phosphorylation sites are highly conserved between IRS-1 and IRS-2 (Sun et al. 1995). The motifs containing phosphorylated tyrosine residues in IRS-1 and IRS-2 serve as docking sites for binding to various proteins having the Src homology-2 (SH2) domain. Among these SH2 proteins, phosphatidylinositol 3-kinase (PI3-kinase) is considered to be particularly important for the insulin-induced glucose uptake that is observed in muscle and adipose tissue via the translocation of a glucose transporter to the plasma membrane (Kanai et al. 1993, Cheatham et al. 1994, Okada et al. 1994). Furthermore, the activation of PI3-kinase has been reported to play an important role in insulin-induced glycogen synthesis and suppression of phosphoenolpyruvate carboxykinase (PEPCK) expression in hepatocytes (Sakaue et al. 1995, Shepherd et al. 1995, Sutherland et al. 1995, Gabbay et al. 1996).

Growth hormone $(\mathrm{GH})$ is known to modulate insulin actions (Davidson 1987). For example, GH-deficient (GHD) subjects have long been recognized as exhibiting increased insulin sensitivity. In fact, the occurrence of fasting hypoglycemia has been demonstrated in GHD children (Wolfsdorf et al. 1983) and adults (Merimee et al. 1971). This notion is supported by studies using animal models such as dwarf rats (Daugaard et al. 1999) and GH 
receptor-knockout mice (Dominici et al. 2000). In contrast, several researchers have recently reported observing insulin resistance in GHD subjects. Cuneo et al. (1992) have reported increased fasting insulin levels in GHD adults. Decreased insulin sensitivity was also shown in GHD adults by the euglycemic-hyperinsulinemic clamp method (Johansson et al. 1995, Hew et al. 1996). In addition, the studies on GHD subjects have shown that $\mathrm{GH}$ deficiency induces fat accumulation, which is one of the major risk factors for developing non-insulindependent diabetes mellitus (NIDDM) with insulin resistance (Kopelman 2000). These recent findings indicate that insulin resistance can occur under the state of $\mathrm{GH}$ deficiency.

In contrast with clinical studies, there have been few reports of studies investigating the relationship between insulin resistance and GH deficiency in animal models. One reason may be that, until recently, no good animal models that exhibit both insulin resistance and $\mathrm{GH}$ deficiency were available. We have previously reported the production of a strain of transgenic rats carrying a chimeric gene of mouse whey acidic protein (WAP) promoter and human $\mathrm{GH}(\mathrm{hGH})$ which exhibit unique phenotypes (Ikeda et al. 1994, 1998). Although hGH is mainly produced in the mammary gland like other transgenic animals having the WAP-hGH gene (Günzburg et al. 1991, Tojo et al. 1993), serum hGH level in this transgenic rat was relatively low. Moreover, the secretion of endogenous rat $\mathrm{GH}(\mathrm{rGH})$ was almost totally suppressed. Despite the low circulating levels of both hGH and $\mathrm{rGH}$, their insulin-like growth factor-I levels and body length were almost normal, while they developed severe obesity and insulin resistance. In addition, blood glucose, insulin, triglyceride and free fatty acid levels, which are known to be indicators of early diabetes, were elevated, and glucose intolerance after a bolus injection of glucose was observed in the transgenic rats. Thus, we believe our transgenic rats are a useful model for investigating the relationship between insulin resistance and impaired GH status.

In the present study, we analyzed the early steps of insulin signaling in the liver of the transgenic rat. Namely, we evaluated the insulin-stimulated tyrosine phosphorylation levels of insulin receptor and IRS-1 and -2 , and the PI3-kinase activity associated with IRS-1 and -2 and the amount of insulin receptor and IRS-1 and -2 in the liver of the transgenic rat. In addition, we determined the association of the p85 subunit of PI3-kinase with phosphotyrosine-containing proteins.

\section{Materials and Methods}

\section{Antibodies}

The anti-insulin receptor $\beta$-subunit (anti-IR- $\beta$ ) antibody, the anti-IRS-1 antibody, the anti-IRS-2 antibody, the
anti-PI3-kinase p85 subunit (anti-PI3Kp85) antibody and the monoclonal anti-phosphotyrosine (anti-pY) antibody were purchased from Upstate Biotechnology (Lake Placid, NY, USA).

\section{Animals}

Generation of the hGH transgenic rats has been described previously (Ikeda et al. 1994). In this experiment, we used the male transgenic rats (heterozygotes) and their male littermates at 17 weeks of age. After being weaned from the mother at 3 weeks of age, the rats were individually housed with continuous free access to laboratory chow and water. They were kept under a constant room temperature $\left(23 \pm 1{ }^{\circ} \mathrm{C}\right)$ and lighting schedule $(12 \mathrm{~h}$ light:12 $\mathrm{h}$ darkness; lights on at $0700 \mathrm{~h}$ ).

\section{Glucose tolerance test}

The animals were fasted overnight and received an i.p. injection of $0.5 \mathrm{~g} / \mathrm{kg}$ body weight D-glucose $(20 \%$ solution). Blood samples were obtained from the tail vein without anesthesia, and glucose concentrations were determined before ( $0 \mathrm{~min})$ and 15, 30, 60, 90, 120 and $150 \mathrm{~min}$ after glucose injection. Plasma glucose was measured using a glucose analyzer (Antsense; MilesSankyo Co. Ltd, Tokyo, Japan) by the immobilized enzyme membrane $/ \mathrm{H}_{2} \mathrm{O}_{2}$ method (Shirai et al. 1991), and the serum concentration of insulin was assessed by the enzyme-linked immunosorbent assay kit (Amersham Pharmacia Biotech, Amersham, Bucks, UK).

\section{Preparation of liver extracts}

The transgenic and control rats were fasted overnight. They were anesthetized with pentobarbital sodium (45 mg/kg body weight, i.p.). After anesthesia, the portal vein was exposed and 1 IU insulin (Novloin R; Novo Nordisk, Bagsvaerd, Denmark) in normal saline in a final volume of $0.1 \mathrm{ml}$ was injected via the vein. Saline was injected to evaluate the basal condition. Approximately $1 \mathrm{~min}$ after the injection, the liver was removed, minced coarsely and homogenized in 10 volumes of homogenization buffer A containing $50 \mathrm{mM}$ Tris (pH 7.4), $150 \mathrm{mM}$ $\mathrm{NaCl}, 1 \% \mathrm{NP}-40,0 \cdot 25 \%$ sodium deoxycholate, $1 \mathrm{mM}$ $\mathrm{Na}_{2} \mathrm{VO}_{4}, 1 \mathrm{mM} \mathrm{NaF}$ and a protease inhibitor cocktail tablet (Complete mini; Boehringer Mannheim $\mathrm{GmbH}$, Mannheim, Germany) at $4{ }^{\circ} \mathrm{C}$. The extracts from the liver were centrifuged briefly to eliminate insoluble material. Protein concentration was determined using a commercial kit (DC protein assay kit; Bio-Rad, Hercules, CA, USA).

\section{Immunoprecipitation}

Liver extracts containing $5 \mathrm{mg}$ total protein were incubated at $4{ }^{\circ} \mathrm{C}$ overnight with $5 \mu \mathrm{g}$ anti-IR- $\beta$, anti-IRS-1 
Table 1 Characteristics of rats used. Data are expressed as means \pm S.E.M. Numbers in parentheses represent the number of animals in each group

\begin{tabular}{|c|c|c|c|}
\hline & $\begin{array}{l}\text { Body weight } \\
\text { (g) }\end{array}$ & $\begin{array}{l}\text { Plasma glucose } \\
(\mathrm{mmol} / \mathrm{l})\end{array}$ & $\begin{array}{l}\text { Serum insulin } \\
(\mathrm{ng} / \mathrm{ml})\end{array}$ \\
\hline \multicolumn{4}{|l|}{ Line $^{a}$} \\
\hline Control rats & $520 \pm 20 \cdot 5(6)$ & $6 \cdot 56 \pm 0 \cdot 18(6)$ & $6.6 \pm 0.9(6)$ \\
\hline Transgenic rats & $670 \pm 26 \cdot 8(4)^{*}$ & $7 \cdot 67 \pm 0 \cdot 25(7)^{*}$ & $22 \cdot 3 \pm 4 \cdot 2$ \\
\hline
\end{tabular}

and -2 and anti-pY antibodies. After incubation, $50 \mu \mathrm{l}$ protein A-Sepharose (Amersham Pharmacia Biotech; 50\% $\mathrm{V} / \mathrm{v}$ ) was added to the mixture. The preparation was further incubated with constant rocking for $2 \mathrm{~h}$ and centrifuged at $3000 \mathrm{~g}$ for $10 \mathrm{~s}$ at $4{ }^{\circ} \mathrm{C}$. The supernatant was discarded, and the precipitate was washed five times with homogenization buffer A. The final pellet was resuspended in $15 \mu \mathrm{l}$ of reducing sample buffer containing $50 \mathrm{mM}$ Tris, 2\% SDS, 10\% glycerol, 6\% 2-mercaptoethanol and $0.02 \%$ bromophenol blue, boiled for $5 \mathrm{~min}$ and stored at $-70{ }^{\circ} \mathrm{C}$ until electrophoresis.

\section{Immunoblotting}

Samples were subjected to SDS-PAGE on a $6 \%$ polyacrylamide gel with a Bio-Rad Mini protein apparatus (Bio-Rad Laboratories, Richmond, CA, USA). Electrotransfer of proteins from the gel to Immobilon $\mathrm{P}$ membranes (Millipore, Bedford, MA, USA ) was performed overnight at $30 \mathrm{~V}$ (constant) with the Bio-Rad miniature transfer apparatus (Bio-Rad Laboratories) in $25 \mathrm{mM}$ Tris, $192 \mathrm{mM}$ glycine, $20 \%$ methanol and 0.05\% SDS. To reduce non-specific antibody binding, the membranes were incubated at $4{ }^{\circ} \mathrm{C}$ overnight in Blockace (a blocking buffer; Yukijirushi, Sapporo, Japan). The membranes were then incubated for $1 \mathrm{~h}$ at room temperature with anti-pY $(1 \mu \mathrm{g} / \mathrm{ml})$, anti-IR- $\beta \quad(1 \mu \mathrm{g} / \mathrm{ml})$, anti-IRS-1 $(1 \mu \mathrm{g} / \mathrm{ml})$, anti-IRS-2 $(1 \mu \mathrm{g} / \mathrm{ml})$ or anti-PI3Kp85 $(1 \mu \mathrm{g} /$ $\mathrm{ml}$ ) antibody diluted in the corresponding blocking buffer. The membranes were washed three times for $10 \mathrm{~min}$ in Tris-buffered saline-Tween 20 buffer containing $10 \mathrm{mM}$ Tris (pH 7.4), $150 \mathrm{mM} \mathrm{NaCl}$ and 0.02\% Tween 20 and were then incubated with optimal second antibodies conjugated with horseradish peroxidase (1:1000) for $1 \mathrm{~h}$ at room temperature. After the membranes had been washed three times for $10 \mathrm{~min}$, they were exposed to X-ray film (Eastman Kodak, Rochester, NY, USA). The pictures were scanned with a scanner (GT-6500; Epson, Tokyo, Japan), and the relative intensity of each band was analyzed using NIH imaging software (NIH, Bethesda, MD, USA).

\section{P13-kinase assay}

The P13-kinase assay was performed essentially as described by Carvalho et al. (1996). Liver extracts containing $5 \mathrm{mg}$ total protein were incubated at $4{ }^{\circ} \mathrm{C}$ overnight with anti-IRS-1 or anti-IRS-2 antibody. Immunocomplexes were collected by centrifugation following the addition of $20 \mu \mathrm{l}$ of a $50 \%(\mathrm{v} / \mathrm{v})$ slurry of protein A-Sepharose in homogenization buffer and further incubation for $2 \mathrm{~h}$ at $4{ }^{\circ} \mathrm{C}$. The immunoprecipitates were washed with ice-cold homogenization buffer A, $100 \mathrm{mM}$ ice-cold Tris ( $\mathrm{pH} 7 \cdot 4$ ) containing $100 \mathrm{mM} \mathrm{LiCl}$ and $100 \mu \mathrm{M} \mathrm{Na}_{3} \mathrm{VO}_{4}$, deionized water and $10 \mathrm{mM}$ ice-cold Tris (pH 7*4) containing $100 \mathrm{mM} \mathrm{NaCl}, 1 \mathrm{mM}$ EDTA and $100 \mu \mathrm{M} \mathrm{Na} \mathrm{Na}_{3} \mathrm{VO}_{4}$. The precipitates were then resuspended in $40 \mu \mathrm{l}$ reaction buffer containing $20 \mathrm{mM}$ Tris (pH 7·5), $100 \mathrm{mM} \mathrm{NaCl}, 0 \cdot 5 \mathrm{mM}$ EGTA and $10 \mu \mathrm{g}$ phosphatidylinositol.

The reaction was started by the addition of $10 \mu \mathrm{l} \quad 150 \mu \mathrm{M}$ ATP containing $20 \mu \mathrm{Ci} \quad\left[\gamma^{32} \mathrm{P}\right] \mathrm{ATP}$ $(6000 \mathrm{Ci} / \mathrm{mmol}), 5 \mathrm{mM} \mathrm{Na} 3 \mathrm{VO}_{4}, 100 \mathrm{mM}$ dithiothreitol and $100 \mathrm{mM} \mathrm{MgCl}{ }_{2}$. After $60 \mathrm{~min}$ at $25^{\circ} \mathrm{C}$, the reaction was terminated by the addition of $100 \mu \mathrm{l}$ methanolchloroform-HCl (10:20:1). Mixtures were centrifuged, and the lower organic phase was applied to silica thinlayer chromatography (TLC) plates (Merck, Darmstadt, Germany) coated with $1 \%(\mathrm{w} / \mathrm{v})$ potassium oxalate. The TLC plate was developed in $\mathrm{CH}_{3} \mathrm{Cl}-\mathrm{CH}_{3} \mathrm{OH}-\mathrm{H}_{2} \mathrm{O}-$ $\mathrm{NH}_{4} \mathrm{OH}$ (43:38:6:6), visualized by autoradiography and quantitated by optimal densitometry as described above.

\section{Statistical analysis}

Results are expressed as means \pm S.E.M. For comparisons, the data were analyzed by ANOVA followed by Student's $t$-test and the difference was considered significant at $P<0 \cdot 05$.

\section{Results}

Data on body weight, blood glucose concentration and serum insulin concentration of the animals studied are summarized in Table 1. The transgenic rats had significantly increased body weight, plasma glucose and serum insulin levels. In addition, the results of a glucose tolerance test are presented in Fig. 1. After a bolus injection of glucose, blood glucose levels were immediately increased in both transgenic and control rats. Then, however, plasma glucose concentrations of the transgenic rats decreased 


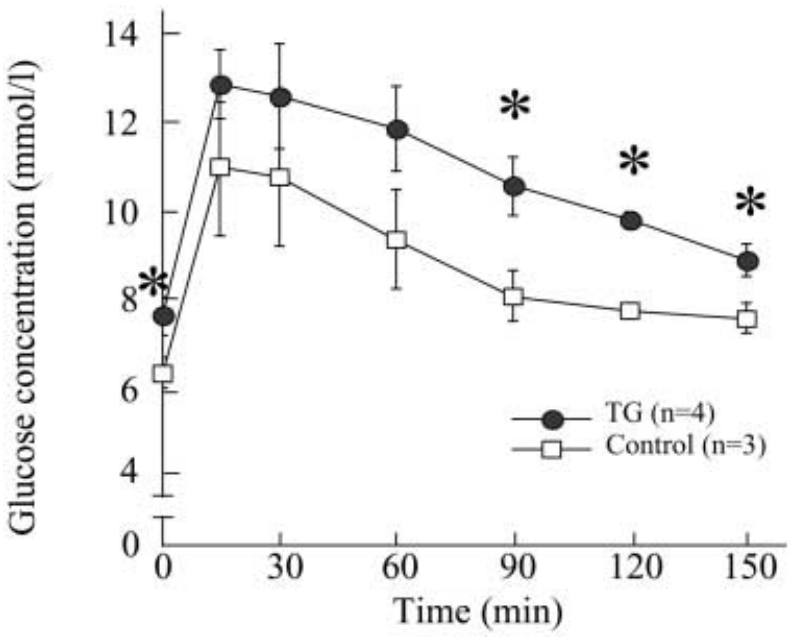

Figure 1 Glucose intolerance in the transgenic rat. Glucose tolerance tests were performed on transgenic and control rats which had been fasted overnight. Animals were injected i.p. with $0.5 \mathrm{~g} / \mathrm{kg}$ body weight D-glucose ( $20 \%$ solution). Plasma glucose was measured immediately before injection $(0)$ and $15,30,60$, 120 and 150 min after injection. Results are expressed as the means \pm S.E.M. from three or four animals. ${ }^{*} P<0 \cdot 01$ vs control.

more modestly compared with those of control rats. The area under the glucose response curve in transgenic rats was $23 \%$ greater than that in control rats $(P<0 \cdot 05)$. These results are indicative of the development of insulin resistance in the transgenic rat.

The amount of insulin receptors, as assessed by Western blotting (WB) of IR- $\beta$, was $49 \%$ decreased in the liver of transgenic rats compared with that of control rats (Fig. 2A). Moreover, autophosphorylation of the insulin receptors in response to exogenous insulin (1 IU/rat) was decreased by $22 \%$ in the liver from transgenic rats (Fig. 2B). To further investigate whether the alteration of the insulin receptor function in the transgenic rats affected downstream elements of the insulin signal transduction cascade, the amount and phosphorylation of IRS-1 and IRS-2 were evaluated. The amount of IRS-1 and IRS-2 in the liver of the transgenic rat was decreased by $31 \%$ and $32 \%$ respectively (Figs 3A and 4A). The basal level of IRS-1 tyrosine phosphorylation in transgenic rats was lower than that of controls (Fig. 3B). As shown in Fig. 3B, i.v. administration of insulin increased IRS-1 phosphorylation in the liver of both control and transgenic rats, but the level of IRS-1 phosphorylation in transgenic rats was $45 \%$ lower than that of control rats. Although basal IRS-2 tyrosine phosphorylation was not different between transgenic and control animals, insulin-stimulated IRS-2 tyrosine phosphorylation in transgenic rats was $16 \%$ lower than that of control rats (Fig. 4B).

For the measurement of PI3-kinase activities, extracts of liver were prepared and immunoprecipitated with antiIRS-1 and anti-IRS-2 antibodies after the rats were
A

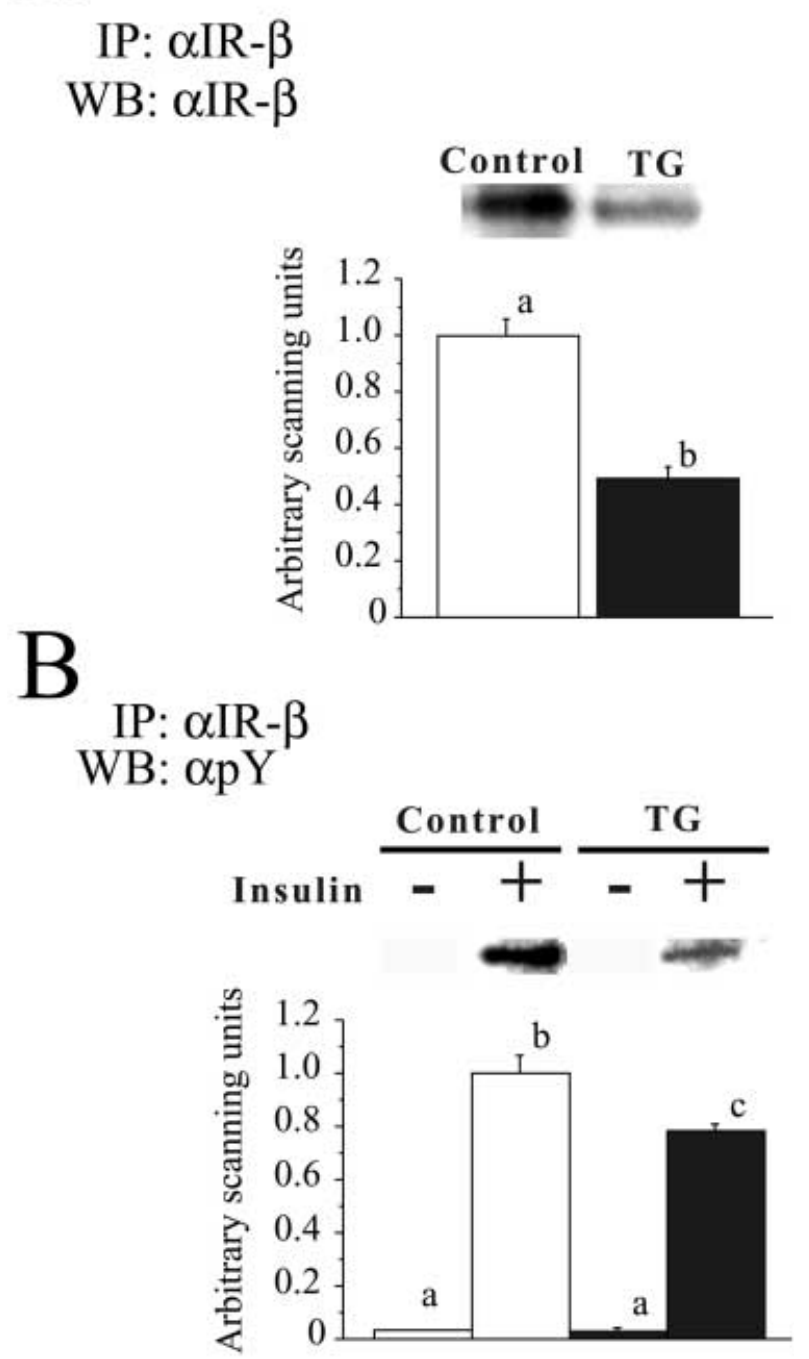

Figure 2 Amounts of insulin receptor $\beta$-subunit protein and tyrosine phosphorylation of insulin receptor in the liver of transgenic (TG) and control rats. Animals were anesthetized, and normal saline ( - ) or insulin (1 IU) (+) was injected into the portal vein. One minute after the injection, the liver was excised and protein was isolated. Equal aliquots of protein were immunoprecipitated (IP) with anti-insulin receptor $\beta$-subunit antibodies $(\alpha \mid \mathrm{I}-\beta)$, and subsequently with protein A-Sepharose. Immunoprecipitated proteins were separated by SDS-PAGE and subjected to immunoblot analysis with the same antibody (A, upper). Quantitation of insulin receptor amount in the liver was performed by scanning densitometry, and expressed as relative to the control value that was set at 1 (A, lower). Data are means \pm S.E.M. of three separate experiments. The same samples were immunoprecipitated with $\alpha$ IR- $\beta$ and immunoblotted with anti-phosphotyrosine antibodies $(\alpha p \mathrm{p})(\mathrm{B}, \mathrm{upper})$. The phosphorylation level of insulin receptor was quantified by scanning densitometry and expressed as relative values (insulin-stimulated control $=1)(B$, lower). Data are means \pm S.E.M. of three separate experiments. Values with different superscripts are significantly different $(P<0 \cdot 05)$. 
A

\section{IP: $\alpha$ IRS- 1 WB: $\alpha$ IRS-1}

\section{Control TG}

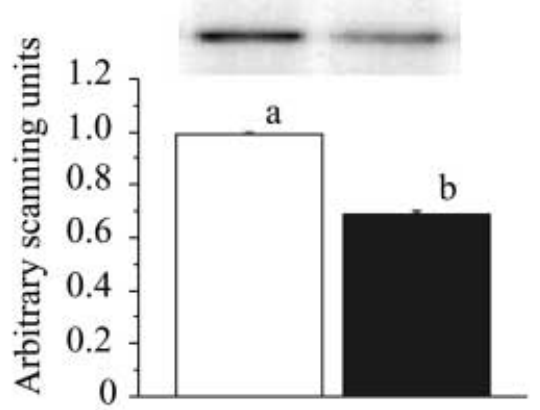

B

\section{IP: $\alpha$ IRS-1 WB: $\alpha p Y$}

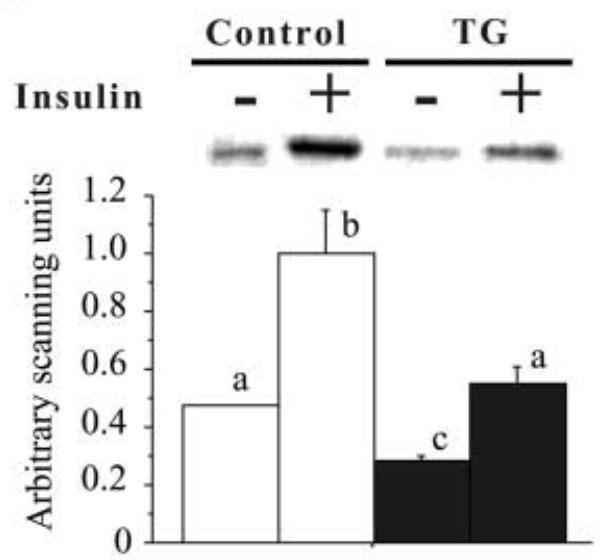

Figure 3 Amounts of insulin receptor substrate (IRS-1) protein and tyrosine phosphorylation of IRS-1 in the liver of transgenic (TG) and control rats. Animals were anesthetized, and normal saline $(-)$ or insulin $(1 \mathrm{IU})(+)$ was injected into the portal vein. One minute after the injection, the liver was excised and protein was isolated from the liver. Equal aliquots of protein were immunoprecipitated (IP) with anti-IRS-1 antibodies ( $\alpha$ IRS- 1 ) and subsequently with protein A-Sepharose. Immunoprecipitated proteins were separated by SDS-PAGE and subjected to immunoblot analysis with the same antibody (A, upper). Quantification of IRS-1 amount in the liver was performed by scanning densitometry and expressed as relative to the control value that was set at 1 (A, lower). Data are means \pm S.E.M. of three separate experiments. The same samples were immunoprecipitated with $\alpha$ IRS- 1 and immunoblotted with anti-phosphotyrosine antibodies ( $\alpha p Y)(B$, upper). Phosphorylation levels of IRS-1 were quantified by scanning densitometry and expressed as relative values (insulin-stimulated control $=1)(B$, lower). Data are means \pm S.E.M. of three separate experiments. Values with different superscripts are significantly different $(P<0 \cdot 01)$.

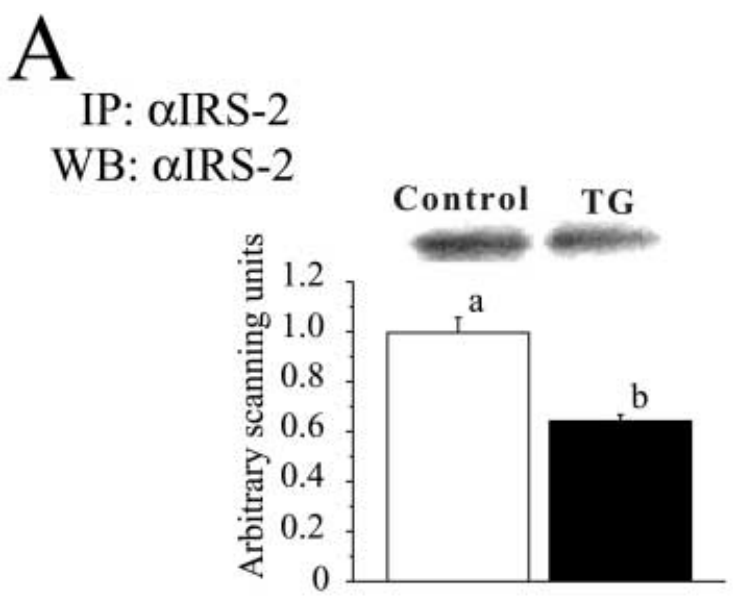

B

\section{IP: $\alpha$ IRS-2 \\ WB: $\alpha p Y$}

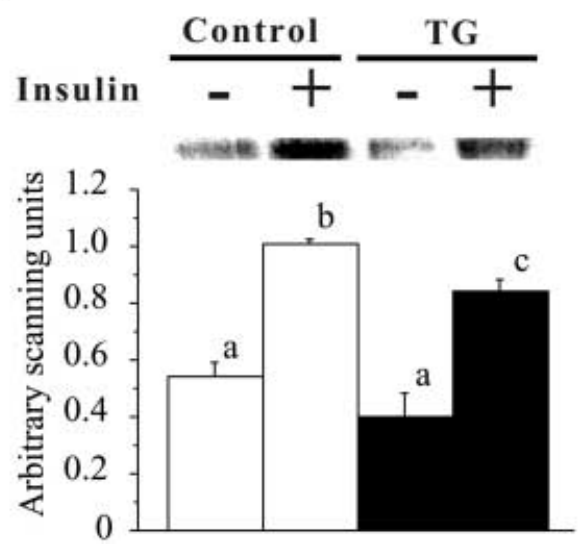

Figure 4 Amounts of IRS-2 protein and tyrosine phosphorylation of IRS-2 in the liver of transgenic (TG) and control rats. Animals were anesthetized, and normal saline $(-)$ or insulin (1 IU) (+) was injected into the portal vein. One minute after the injection, the liver was excised and protein was isolated from the liver. Equal aliquots of protein were immunoprecipitated (IP) with anti-IRS-2 antibodies ( $\alpha$ IRS-2) and subsequently with protein A-Sepharose. Immunoprecipitated proteins were separated by SDS-PAGE and subjected to immunoblot analysis with the same antibody (A, upper). Quantification of IRS-2 abundance in the liver was performed by scanning densitometry and expressed as relative to the control value that was set at 1 (A, lower). Data are means \pm S.E.M. of three separate experiments. The same samples were immunoprecipitated with $\alpha$ IRS-2 and immunoblotted with anti-phosphotyrosine antibodies ( $\alpha p Y)(B$, upper). Phosphorylation levels of IRS-2 were quantified by scanning densitometry and expressed as relative values (insulin-stimulated control $=1$ ) (B, lower). Data are means \pm S.E.M. of three separate experiments. Values with different superscripts are significantly different $(P<0 \cdot 01)$. 

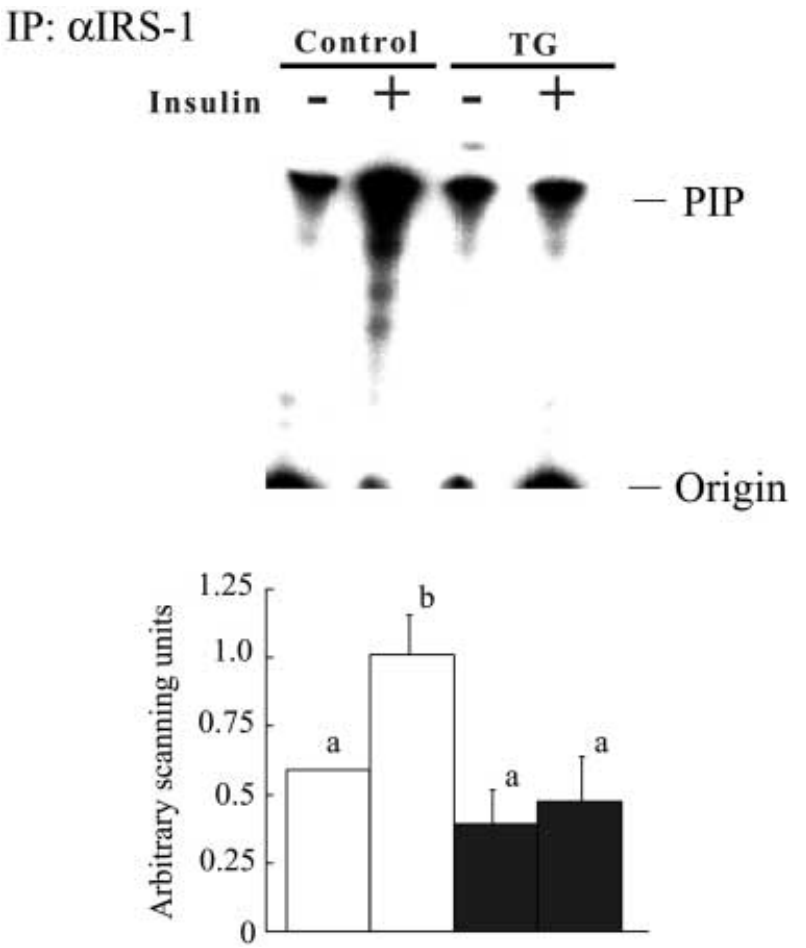

Figure 5 Phosphatidylinositol 3-kinase (PI3-kinase) activity associated with IRS-1 in the liver of the transgenic (TG) and control rats. Animals were anesthetized, and normal saline $(-)$ or insulin (1 IU) (+) was injected into the portal vein. One minute after the injection, the liver was excised and protein was isolated from the liver. Equal aliquots of protein were immunoprecipitated (IP) with anti-IRS- 1 antibodies ( $\alpha$ IRS- 1 ) and subsequently with protein A-Sepharose. PI3-kinase was assayed in the immunoprecipitates in the presence of phosphatidylinositol and $\left[\gamma-{ }^{32}\right.$ P]ATP. The resulting labeled lipids were extracted and separated by TLC (upper). Quantification of PI3-kinase activity associated with IRS-1 in the liver was performed by scanning densitometry and expressed as relative to the control value that was set at 1 (lower). Data are means \pm S.E.M. of three separate experiments. Values with different superscripts are significantly different $(P<0 \cdot 01)$. PIP, phosphatidylinositol.

injected with insulin or saline. There was no significant difference in basal hepatic PI3-kinase activity associated with IRS-1 and IRS-2 between transgenic and control rats. Although insulin markedly stimulated hepatic PI3kinase activity in control rats, it did not affect it in the transgenic rats. Insulin-stimulated PI3-kinase activity associated with IRS-1 and IRS-2 in transgenic rats was smaller by $62 \%$ and $60 \%$ respectively than that in the control rats (Figs 5 and 6). To determine whether the binding levels of the PI3-kinase regulatory subunit, p85 subunit, to the phosphotyrosine in IRSs were altered in the transgenic animals, the amount of $\mathrm{p} 85$ subunit in the immunoprecipitates by anti-pY antibody was analyzed by immunoblotting. The levels of $\mathrm{p} 85$ subunit associated with phosphotyrosine in the transgenic rats were not significantly different from the levels in control rats. Insulin

\section{IP: $\alpha$ IRS-2}
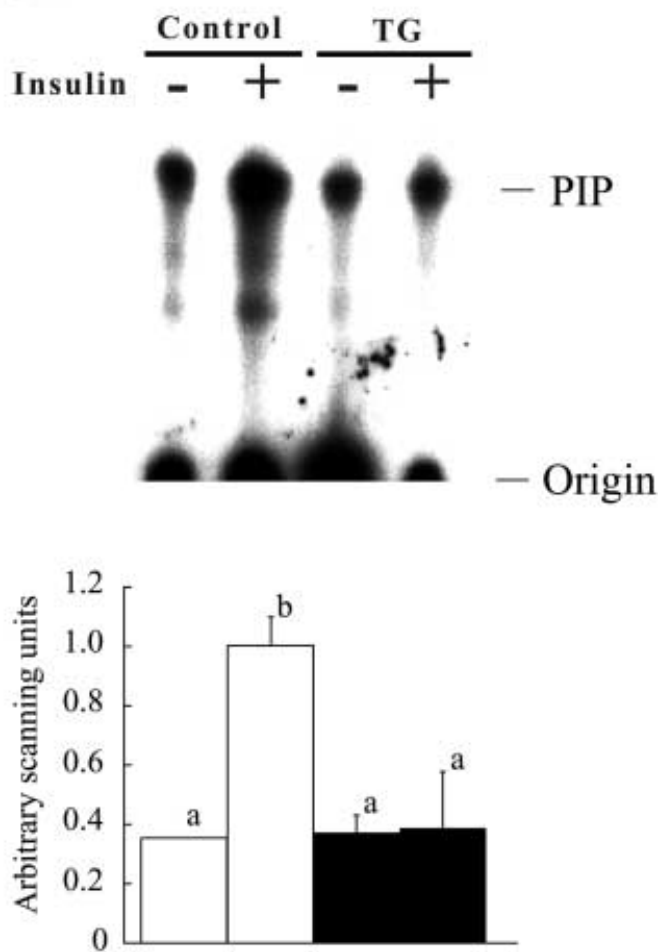

Figure 6 PI3-kinase activity associated with IRS-2 in the liver of transgenic (TG) and control rats. Animals were anesthetized, and normal saline $(-)$ or insulin $(1 \mathrm{IU})(+)$ was injected into the portal vein. One minute after the injection, the liver was excised and protein was isolated from the liver. Equal aliquots of protein were immunoprecipitated (IP) with anti-IRS-2 antibodies ( $\alpha$ IRS-2) and subsequently with protein A-Sepharose. PI3-kinase was assayed in the immunoprecipitates in the presence of phosphatidylinositol and $\left[\gamma-{ }^{32}\right.$ P]ATP. The resulting labeled lipids were extracted and separated by TLC (upper). Quantification of PI3-kinase activity associated with IRS-2 in the liver was performed by scanning densitometry and expressed as relative to the control value that was set at 1 (lower). Data are means \pm S.E.M. of three separate experiments. Values with different superscripts are significantly different $(P<0 \cdot 01)$. PIP, phosphatidylinositol.

significantly increased p85 subunit associated with phosphotyrosine in the controls but not in the transgenic rats (Fig. 7). The amount of p85 subunit in the immunoprecipitates in transgenic rats was $40 \%$ smaller than that in control rats.

\section{Discussion}

The transgenic rat with low circulating GH levels used in the present study exhibited impaired glucose tolerance as well as increased plasma glucose and insulin levels. These results suggest that insulin resistance took place in the transgenic rat, supporting our previous report (Ikeda et al. 1998). Although many researchers have reported that 


\section{IP: $\alpha p Y$ \\ WB: $\alpha$ PI3K-p85}

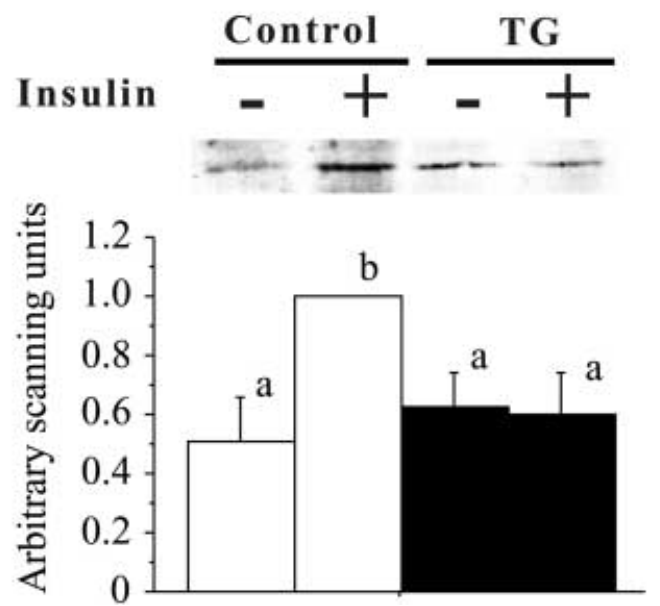

Figure 7 Amount of PI3-kinase p85 subunit (phosphotyrosine immunoprecipitable) in the liver of transgenic (TG) and control rats. Animals were anesthetized, and normal saline $(-)$ or insulin (1 IU) (+) was injected into the portal vein. One minute after the injection, the liver was excised and protein was isolated from the liver as described in Materials and Methods. Equal aliquots of protein were immunoprecipitated (IP) with anti-phosphotyrosine antibodies $(\alpha P Y)$ and subsequently with protein A-Sepharose. Immunoprecipitated proteins were separated by SDS-PAGE and subjected to immunoblot analysis with PI3-kinase p85 subunit antibody ( $\alpha$ PI3K-p85) (upper). Quantification of p85 subunit in the immunoprecipitates in the liver was performed by scanning densitometry, and expressed as relative to the control value that was set at 1 (lower). Data are means \pm S.E.M. of three separate experiments. Values with different superscripts are significantly different $(P<0 \cdot 01)$.

GHD subjects tend to have increased body fat mass (de Boer et al. 1995), controversy exists as to whether GHD adults are indeed insulin sensitive (Merimee et al. 1971, Wolfsdorf et al. 1983) or insulin resistant (Cuneo et al. 1992, Johansson et al. 1995, Hew et al. 1996). Our transgenic rats indicate that GH deficiency can cause insulin resistance, at least under specific conditions.

Insulin signaling is initiated by the activation of insulin receptor tyrosine kinase, leading to the phosphorylation of intracellular receptor substrates, including IRS-1 and -2 (Sun et al. 1993, 1995), and the activation of PI3-kinase associated with IRS-1 and -2. To understand the mechanism of insulin resistance observed in the transgenic rat, it is important to analyze these earlier events in insulin signaling. Thus, in the present study, we first measured the amount of insulin receptor in the liver of transgenic rats by WB and found that transgenic rats had decreased insulin receptor levels. It has been reported that insulin receptor was decreased when circulating insulin levels were increased (Gavin et al. 1974, Kahn et al. 1978, Vigneri et al. 1978, Almira \& Reddy 1979). In addition, it has been reported that GH does not directly affect insulin receptor levels in both in vivo (Dominici et al. 1998) and in vitro (Lesniak \& Roth 1979, Maloff et al. 1980) experiments. Since elevated circulating insulin levels were observed after 12 weeks of age in transgenic rats (Ikeda et al. 1998), decreased insulin receptor levels may result from hyperinsulinemia rather than from low GH levels. Insulinstimulated phosphorylation of insulin receptor was also proportionally suppressed in transgenic rats, indicating that insulin resistance in the liver is initiated at the receptor level.

The amount of both IRS-1 and -2 protein in the liver of transgenic rats was decreased compared with that of controls. It has been reported that IRS-1 protein was moderately increased in the liver of streptozotocin-treated rats, in which insulin was virtually absent (Saad et al. 1992). Conversely, hyperinsulinemic ob/ob mice and Zucker rats showed reduced IRS-1 (Saad et al. 1992), and both IRS-1 and -2 (Anai et al. 1998) proteins in the liver respectively. These findings suggest that IRS-1 and -2 levels are inversely related to circulating insulin levels. Accordingly, decreased IRS-1 and -2 in the liver may be related to hyperinsulinemia in transgenic rats. However, since transgenic mice overexpressing GH display normal concentrations of IRS-1 in the liver despite hyperinsulinemia (Dominici et al. 1999), the possibility that other factors, such as changes in the concentrations of glucose or counter-regulatory hormones (including GH), are involved in the regulation of IRS levels cannot be ruled out.

The tyrosine phosphorylation of IRS- 1 in the basal state of the transgenic rat was significantly decreased compared with that of controls. This may be secondary to the decreased IRS-1 protein level. However, although the amount of IRS-2 was also similarly decreased, no significant change in basal tyrosine phosphorylation levels of IRS-2 was observed between transgenic and control rats. This suggests the existence of different regulatory mechanisms in basal tyrosine phosphorylation levels of the IRS-1 and -2 in the liver. GH has been shown to stimulate tyrosine phosphorylation of IRS-1 in vivo (Yamauchi et al. 1998, Thirone et al. 1999). In addition, it has been reported that GH transgenic mice show an increased basal tyrosine phosphorylation of IRS-1, which might be one of the causes of insulin resistance in those mice (Dominici et al. 1999). Thus, impaired GH level in the transgenic rats may affect basal tyrosine phosphorylation of IRS-1 in the liver of those rats.

Recent evidence has indicated that PI3-kinase is a key enzyme in the insulin-signaling pathway for glucose metabolism. PI3-kinase activation might be essential for insulin-stimulated glucose transport (Kanai et al. 1993, Cheatham et al. 1994, Okada et al. 1994), and PI3-kinase inhibitor has been shown to block insulin-stimulated glucose transport and GLUT4 translocation in rats and 
3T3-L1 adipocytes (Clarke et al. 1994, Sanchez-Margalet et al. 1994). In hepatocytes, PI3-kinase also plays an important role in glycogen synthesis via c-akt activation (Sakaue et al. 1995, Shepherd et al. 1995). In addition, insulin suppresses the gene expression of PEPCK, the rate-limiting enzyme of gluconeogenesis in the liver, via PI3-kinase activation (Sutherland et al. 1995, Gabbay et al. 1996). These findings suggest that PI3-kinase is essential for insulin-stimulated glucose metabolism in the liver. Impaired PI3-kinase activation has been demonstrated in various insulin-resistant diabetic animal models, such as ob/ob mice (Folli et al. 1993) and Zucker rats (Anai et al. 1998). In humans, it has been reported that the activation of PI3-kinase in the skeletal muscle of obese subjects is markedly suppressed as compared with that of control subjects (Goodyear et al. 1995). In the present study, although insulin-stimulated tyrosine phosphorylation of IRS-1 and -2 in transgenic rats was only partially impaired as compared with controls, the insulin effect on PI3-kinase activity associated with IRS-1 and -2 was not discernible in transgenic rats. The discrepancy between tyrosine phosphorylation of IRSs and PI3-kinase activation associated with IRSs was also reported in Zucker rats (Anai et al. 1998). This phenomenon observed in both our transgenic and Zucker rats might be common among obese early stage NIDDM models.

The association of IRS-1 and -2 with PI3-kinase occurs through the phosphorylated tyrosine residue on IRS-1 and -2 and SH2 domains on the regulatory subunit of PI3kinase (Backer et al. 1992). To elucidate whether this discrepancy results from alterations in the binding of IRSs and the regulatory subunit of PI3-kinase, we detected the p85 subunit of PI3-kinase in the immunoprecipitates with anti-phosphotyrosine antibody by WB. We found that insulin did not stimulate the binding of $\mathrm{p} 85$ subunit to tyrosine-phosphorylated proteins in transgenic rats at all. This suggests that, although the insulin-signaling pathway is impaired at multiple steps in transgenic rats, insulin resistance mainly takes place at the level of binding of the p85 subunit to the phosphotyrosine of IRSs. For PI3kinase activation, binding of the $\mathrm{SH} 2$ domain of the $\mathrm{p} 85$ subunit of PI3-kinase to phosphorylated YMXM or YXXM motifs is necessary (Backer et al. 1992). Although IRS-1 and -2 contain over 20 potential tyrosine phosphorylation sites (Sun et al. 1993, 1995), phosphorylation of tyrosine residues different from the YMXM and YXXM motifs would not contribute to the activation of PI3kinase. If this is the case, a selective decrease in phosphorylation of the tyrosine residues in the YMXM or YXXM motifs of IRS-1 and -2 may occur in the liver of transgenic rats.

Serine/threonine phosphorylations in IRS proteins may also be involved in impaired insulin signaling in transgenic rats. It has been demonstrated that IRS proteins contain more than 70 potential serine/threonine phosphorylation sites (Sun et al. 1993, 1995), and that serine/threonine phosphorylation of IRS-1 impairs the ability of IRS-1 to associate with the insulin receptor, which inhibits subsequent insulin-stimulated tyrosine phosphorylation (Paz et al. 1997). In addition, it has also been reported that serine/threonine phosphorylation in IRS-1 is increased in subjects with insulin resistance and NIDDM (Virkamaki et al. 1999), and that cytokines, which induce insulin resistance, promote serine phosphorylation of IRS-1 (Kanety et al. 1995, Hotamisligil et al. 1996, Peraldi et al. 1996). Taken together, serine/threonine phosphorylation in IRS proteins seems to play an important role in the development of insulin resistance.

In conclusion, insulin resistance in transgenic rats with low circulating GH levels is characterized by impaired PI3-kinase activation by insulin in the liver due to decreased association of the p85 subunit with phosphotyrosine residues, although decreases in insulin-stimulated tyrosine phosphorylation of insulin receptor and IRS-1 and -2 , as well as decreases in the amount of these proteins also take place. How GH deficiency induces the blockade of the p85 subunit binding to IRSs remains to be elucidated.

\section{Acknowledgements}

The present work was financially supported in part by a Grant-in-Aid from the Scientific Research Fund of the Ministry of Education, Science, Culture and Sports, Japan, and by the 'Research for the Future' Program of the Japan Society for the Promotion of Science (JSPS-RFTF 97L00904).

\section{References}

Almira EC \& Reddy WJ 1979 Effect of fasting on insulin binding to hepatocytes and liver plasma membranes from rats. Endocrinology 104 205-211.

Anai M, Funaki M, Ogihara T, Terasaki J, Inukai K, Katagiri H, Fukushima Y, Yazaki Y, Kikuchi M, Oka Y \& Asano T 1998 Altered expression levels and impaired steps in the pathway to phosphatidylinositol 3-kinase activation via insulin receptor substrates 1 and 2 in Zucker fatty rats. Diabetes 47 13-23.

Backer JM, Myers MG Jr, Shoelson SE, Chin DJ, Sun XJ, Miralpeix M, Hu P, Margolis B, Skolnik EY, Schlessinger J \& White MF 1992 Phosphatidylinositol $3^{\prime}$-kinase is activated by association with IRS-1 during insulin stimulation. EMBO Journal 11 3469-3479.

de Boer H, Blok GJ \& Van der Veen EA 1995 Clinical aspects of growth hormone deficiency in adults. Endocrine Reviews 16 63-86.

Carvalho CR, Brenelli SL, Silva AC, Nunes AL, Velloso LA \& Saad MJ 1996 Effect of aging on insulin receptor, insulin receptor substrate-1, and phosphatidylinositol 3-kinase in liver and muscle of rats. Endocrinology 137 151-159.

Cheatham B, Vlahos CJ, Cheatham L, Wang L, Blenis J \& Kahn CR 1994 Phosphatidylinositol 3-kinase activation is required for insulin stimulation of pp70 S6 kinase, DNA synthesis, and glucose transporter translocation. Molecular and Cellular Biology 14 4902-4911.

Clarke JF, Young PW, Yonezawa K, Kasuga M \& Holman GD 1994 Inhibition of the translocation of GLUT1 and GLUT4 in 3T3-L1 
cells by the phosphatidylinositol 3-kinase inhibitor, wortmannin. Biochemical Journal 300 631-635.

Cuneo RC, Salomon F, McGauley GA \& Sonksen PH 1992 The growth hormone deficiency syndrome in adults. Clinical Endocrinology 37 387-397.

Daugaard JR, Laustsen JL, Hansen BS \& Richter EA 1999 Insulin action in growth hormone-deficient and age-matched control rats: effect of growth hormone treatment. Journal of Endocrinology 160 $127-135$

Davidson MB 1987 Effect of growth hormone on carbohydrate and lipid metabolism. Endocrine Reviews 8 115-131.

Dominici FP, Balbis A, Bartke A \& Turyn D 1998 Role of hyperinsulinemia on hepatic insulin receptor concentration and autophosphorylation in the presence of high growth hormone levels in transgenic mice overexpressing growth hormone gene. Journal of Endocrinology 159 15-25.

Dominici FP, Cifone D, Bartke A \& Turyn D 1999 Loss of sensitivity to insulin at early events of the insulin signaling pathway in the liver of growth hormone-transgenic mice. Journal of Endocrinology $161383-392$.

Dominici FP, Arostegui Diaz G, Bartke A, Kopchick J \& Turyn D 2000 Compensatory alterations of insulin signal transduction in liver of growth hormone receptor knockout mice. Journal of Endocrinology $166579-590$.

Folli F, Saad MJ, Backer JM \& Kahn CR 1993 Regulation of phosphatidylinositol 3-kinase activity in liver and muscle of animal models of insulin-resistant and insulin-deficient diabetes mellitus. Journal of Clinical Investigation 92 1787-1794.

Gabbay RA, Sutherland C, Gnudi L, Kahn BB, O'Brien RM, Granner DK \& Flier JS 1996 Insulin regulation of phosphoenolpyruvate carboxykinase gene expression does not require activation of the Ras/mitogen-activated protein kinase signaling pathway. Journal of Biological Chemistry 271 1890-1897.

Gavin JR 3rd, Roth J, Neville DM Jr, de Meyts P \& Buell DN 1974 Insulin-dependent regulation of insulin receptor concentrations: a direct demonstration in cell culture. PNAS 71 84-88.

Goodyear LJ, Giorgino F, Sherman LA, Carey J, Smith RJ \& Dohm GL 1995 Insulin receptor phosphorylation, insulin receptor substrate-1 phosphorylation, and phosphatidylinositol 3-kinase activity are decreased in intact skeletal muscle strips from obese subjects. Journal of Clinical Investigation 95 2195-2204.

Günzburg WH, Salmons B, Zimmermann B, Müller M, Erfle V \& Brem G 1991 A mammary-specific promoter directs expression of growth hormone not only to the mammary gland, but also to Bergman glia cells in transgenic mice. Molecular Endocrinology 5 123-133.

Hew FL, Koschmann M, Christopher M, Rantzau C, Vaag A, Ward G, Beck-Nielsen H \& Alford F 1996 Insulin resistance in growth hormone-deficient adults: defects in glucose utilization and glycogen synthase activity. Journal of Clinical Endocrinology and Metabolism 81 555-564.

Hotamisligil GS, Peraldi P, Budavari A, Ellis R, White MF \& Spiegelman BM 1996 IRS-1-mediated inhibition of insulin receptor tyrosine kinase activity in TNF-alpha- and obesity-induced insulin resistance. Science 271 665-668.

Ikeda A, Matsuyama S, Nishihara M, Tojo H \& Takahashi M 1994 Changes in endogenous growth hormone secretion and onset of puberty in transgenic rats expressing human growth hormone gene. Endocrine Journal 41 523-529.

Ikeda A, Chang KT, Matsumoto Y, Furuhata Y, Nishihara M, Sasaki F \& Takahashi M 1998 Obesity and insulin resistance in human growth hormone transgenic rats. Endocrinology 139 3057-3063.

Johansson JO, Fowelin J, Landin K, Lager I \& Bengtsson BA 1995 Growth hormone-deficient adults are insulin-resistant. Metabolism: Clinical and Experimental 44 1126-1129.
Kahn CR, Goldfine ID, Neville DM Jr \& De Meyts P 1978 Alterations in insulin binding induced by changes in vivo in the levels of glucocorticoids and growth hormone. Endocrinology 103 1054-1066.

Kanai F, Ito K, Todaka M, Hayashi H, Kamohara S, Ishii K, Okada T, Hazeki O, Ui M \& Ebina Y 1993 Insulin-stimulated GLUT4 translocation is relevant to the phosphorylation of IRS-1 and the activity of PI3-kinase. Biochemical and Biophysical Research Communications 195 762-768.

Kanety H, Feinstein R, Papa MZ, Hemi R \& Karasik A 1995 Tumor necrosis factor $\alpha$-induced phosphorylation of insulin receptor substrate-1 (IRS-1). Possible mechanism for suppression of insulin-stimulated tyrosine phosphorylation of IRS-1. Journal of Biological Chemistry 270 23780-23784.

Kopelman PG 2000 Obesity as a medical problem. Nature 404 635-643.

Lesniak MA \& Roth J 1976 Regulation of receptor concentration by homologous hormone. Effect of human growth hormone on its receptor in IM-9 lymphocytes. Journal of Biological Chemistry 251 3720-3729.

Maloff BL, Levine JH \& Lockwood DH 1980 Direct effects of growth hormone on insulin action in rat adipose tissue maintained in vitro. Endocrinology 107 538-544.

Merimee TJ, Felig P, Marliss E, Fineberg SE \& Cahill GG Jr 1971 Glucose and lipid homeostasis in the absence of human growth hormone. Journal of Clinical Investigation 50 574-582.

Okada T, Kawano Y, Sakakibara T, Hazeki O \& Ui M 1994 Essential role of phosphatidylinositol 3-kinase in insulin-induced glucose transport and antilipolysis in rat adipocytes. Studies with a selective inhibitor wortmannin. Journal of Biological Chemistry 269 3568-3573.

Paz K, Hemi R, LeRoith D, Karasik A, Elhanany E, Kanety H \& Zick Y 1997 A molecular basis for insulin resistance. Journal of Biological Chemistry 272 29911-29918.

Peraldi P, Hotamisligil GS, Buurman WA, White MF \& Spiegelman BM 1996 Tumor necrosis factor (TNF)-alpha inhibits insulin signaling through stimulation of the p55 TNF receptor and activation of sphingomyelinase. Journal of Biological Chemistry 271 13018-13022.

Saad MJ, Araki E, Miralpeix M, Rothenberg PL, White MF \& Kahn CR 1992 Regulation of insulin receptor substrate-1 in liver and muscle of animal models of insulin resistance. Journal of Clinical Investigation 90 1839-1849.

Sakaue H, Hara K, Noguchi T, Matozaki T, Kotani K, Ogawa W, Yonezawa K, Waterfield MD \& Kasuga M 1995 Ras-independent and wortmannin-sensitive activation of glycogen synthase by insulin in Chinese hamster ovary cells. Journal of Biological Chemistry 270 11304-11309.

Sanchez-Margalet V, Goldfine ID, Vlahos CJ \& Sung CK 1994 Role of phosphatidylinositol-3-kinase in insulin receptor signaling: studies with inhibitor, LY294002. Biochemical and Biophysical Research Communications 204 446-452.

Shepherd PR, Nave BT \& Siddle K 1995 Insulin activates glycogen synthase by a novel PI 3-kinase/p70s6k dependent pathway in 3T3-L1 adipocytes. Biochemical Society Transactions 23 202S.

Shirai H, Douman K \& Ikeda Y 1991 Performance of Ames Antsence, a new table-top blood glucose analyzer based on immobilized enzyme membrane $/ \mathrm{H}_{2} \mathrm{O}_{2}$ electrode method. The Clinical Report $\mathbf{2 5}$ $2877-2883$.

Sun XJ, Crimmins DL, Myers MG Jr, Miralpeix M \& White MF 1993 Pleiotropic insulin signals are engaged by multisite phosphorylation of IRS-1. Molecular and Cellular Biology 13 $7418-7428$.

Sun XJ, Wang LM, Zhang Y, Yenush L, Myers MG Jr, Glasheen E, Lane WS, Pierce JH \& White MF 1995 Role of IRS-2 in insulin and cytokine signalling. Nature 377 173-177.

Sutherland C, O'Brien RM \& Granner DK 1995 Phosphatidylinositol 3-kinase, but not $\mathrm{p} 70 / \mathrm{p} 85$ ribosomal S6 protein kinase, is required 
for the regulation of phosphoenolpyruvate carboxykinase (PEPCK) gene expression by insulin. Dissociation of signaling pathways for insulin and phorbol ester regulation of PEPCK gene expression. Journal of Biological Chemistry 270 15501-15506.

Thirone AC, Carvalho CR \& Saad MJ 1999 Growth hormone stimulates the tyrosine kinase activity of JAK2 and induces tyrosine phosphorylation of insulin receptor substrates and She in rat tissues. Endocrinology 140 55-62.

Tojo H, Tanaka S,Matsuzawa A, Takahashi M \& Tachi C 1993 Production and characterization of transgenic mice expressing a hGH fusion gene driven by the promoter of mouse whey acidic protein (mWAP) putatively specific to mammary gland. Journal of Reproduction and Development 39 145-155.

Vigneri R, Pliam NB, Cohen DC, Pezzino V, Wong KY \& Goldfine ID 1978 In vivo regulation of cell surface and intracellular insulin binding sites by insulin. Journal of Biological Chemistry 253 8192-8197.
Virkamaki A, Ueki K \& Kahn CR 1999 Protein-protein interaction in insulin signaling and the molecular mechanisms of insulin resistance. Journal of Clinical Investigations 103 931-943.

Wolfsdorf JI, Sadeghi-Nejad A \& Senior B 1983 Hypoketonemia and age-related fasting hypoglycemia in growth hormone deficiency. Metabolism: Clinical and Experimental 32 457-462.

Yamauchi T, Kaburagi Y, Ueki K, Tsuji Y, Stark GR, Kerr IM, Tsushima T, Akanuma Y, Komuro I, Tobe K, Yazaki Y \& Kadowaki T 1998 Growth hormone and prolactin stimulate tyrosine phosphorylation of insulin receptor substrate-1, -2 , and -3 , their association with p 85 phosphatidylinositol 3-kinase (PI3-kinase), and concomitantly PI3-kinase activation via JAK2 kinase. Journal of Biological Chemistry 273 15719-15726.

Received in final form 18 September 2001 Accepted 4 October 2001 